\title{
'THE STOLEN SPACE': A HISTORY OF CHANNELIZATION, REDUCTION OF RIVERINE AREAS AND RELATED MANAGEMENT ISSUES. THE LOWER SCRIVIA RIVER CASE STUDY (NW ITALY)
}

\author{
ANDREA MANDARINO ${ }^{1}$, MICHAEL MAERKER ${ }^{2} \&$ MARCO FIRPO $^{1}$ \\ ${ }^{1}$ Department of Earth, Environment and Life Sciences, University of Genova, Italy. \\ ${ }^{2}$ Department of Earth and Environment Sciences, University of Pavia, Italy.
}

\begin{abstract}
In this research, we present the lower Scrivia River planform changes occurred from 1878 to 2016. Furthermore, we illustrate the channelization-works development and the land-use changes registered close to the riverbed after the 1950s. The Scrivia River is among the most relevant right-bank tributaries of the Po River; it is about $90 \mathrm{~km}$ long and origins from the Ligurian-Piedmontese Appennines. The study reach is about $16 \mathrm{~km}$ long, close to the Po River, and generally shows a single-thread, sinuous and deep-incised channel. Nowadays the lower Scrivia River presents many bank retreat processes that involve surrounding areas, creating serious management issues. The aim of this research is to outline in detail the active-channel morphological evolution over the last 100-150 years, and characterize channelization and riverscape changes, with a specific focus on the occupation of the areas of fluvial pertinence. A quantitative multi-temporal analysis supported by field surveys and based on historical maps, aerial photographs and satellite images was performed in a GIS environment through automated and semi-automated procedures. The active channel experienced a well-defined sequence of morphological evolutionary phases. They were substantially characterized by a gradual increase of the active-channel stability and a reduction of the active-channel width, up to the end of the 20th century. Since the 2000s, morphological evolutionary trends have changed. Anthropic pressures on the river system, and in particular bank protections, are documented to have played a key role in driving the active-channel changes, and consequently, the near-riverbed land-property and land-use changes. In this respect, on the basis of cadastral data, the past legal framework is also identified as a relevant conditioning factor of the river-corridor morphological evolution. The ongoing dynamics most probably represent the morphological response to the documented, severe anthropic alterations, and are currently raising serious management issues.
\end{abstract}

Keywords: Bank Protection, Channel Planform Changes, Channelization, GIS, Italian Rivers, Land Property, Land Use, Regulations, River Corridor, Scrivia River.

\section{INTRODUCTION}

From the 19th century onwards, most of the Italian rivers experienced relevant morphological changes, mainly due to anthropic interventions [1]-[3]. The most intense active-channel morphological variations consisting of narrowing and incision, occurred in the 2 nd half of the 20th century, and was mainly due to sediment mining and channelization [3]-[5]. Simultaneously, agriculture, facilities and infrastructures spread over floodplain areas, getting closer and closer to the active-channel banks, and occupying areas of fluvial pertinence [6], [7]. This process resulted in an increase of river-related risks and promoted the loss of fluvial habitats. Therefore, the past and present relationships between riverbed changes on the one hand, and land property and land use changes close to riverbeds on the other hand, should be investigated in order to better outline the historical and recent riverscape evolution, its driving factors and the ongoing morphological dynamics. Nevertheless, as we know, there is no evidence in scientific literature about this topic and few documents and reports are available only [8]-[14]. From the 1990s onwards, a slight inversion of the aforementioned morphodynamic trends has been documented along a number of Italian rivers [1], [3], 
[6], [7], [15], [16]. Channel widening and reactivation of morphological processes characterize this current phase, whose triggering factors are still quite debated in scientific literature [15], [16].

This paper describes the lower Scrivia River planform changes occurred since 1878, as already partly documented by previous researches [6]. Moreover, it outlines the extent of bank protections, and the land-use variations occurred close to the riverbed, from the $1950 \mathrm{~s}$ onwards. Finally, it focuses on the conversion of lands belonging to the active channel before the most intense phase of human-induced riverbed morphological alterations. The aim of this research is to outline in detail the channel morphological evolutionary trends over the last $100-150$ years, and characterize channelization and riverscape changes, with a specific focus on the human-activities occupation of the areas of fluvial pertinence. The main novelty of the present work compared to previous papers on Italian regulated rivers [1]-[3] is that a general overview on the Italian regulations concerning land ownership and riverbed morphological changes is provided, and that cadastral data are investigated to assess the legal-framework role in conditioning the river-corridor morphological evolution.

\section{RIVERINE-AREAS OWNERSHIP AND RIVERBED CHANGES: THE HISTORICAL AND LEGAL ITALIAN BACKGROUND}

Fluvial processes generally modify the area close to rivers, changing fluvial forms, surfaces and thus land property extent, particularly in floodplains. From the earliest times, law has regulated these situations. In Italy, during the second half of the 20th century, that is when riverbeds experienced remarkable changes and the most intense human-induced alterations [1]-[3], [5], the national Civil Code dated back to 1942 and still in force, regulated the attribution of riverine-land property. The riverbed has been defined as unalienable state property and its extension, in terms of property, as the surface located below the ordinary-flood level, corresponding to the annual maximum water level exceeded or equalled in the $75 \%$ of historical records, at the considered channel cross-section.

In case of channel migration, the Civil Code substantially stated that: (1) progressivelyabandoned surfaces by the river, due to natural causes, could be freely acquired by the frontager; (2) plots of land instantaneously-moved from one bank-side to the other one due to avulsion, became property of the receiving bank-side frontager upon payment of an indemnity; (3) abandoned riverbeds were distributed among frontagers according to their property extension along banks, and up to the abandoned-channel centreline. Moreover, state-owned riverine plots of land were often given on concession for agriculture, to frontagers preferentially, in accordance with a law dated 1936. This legal framework substantially followed the regulations already established by the first Italian Civil Code dated back to 1865, and promoted land use for income purposes, reflecting the historical background from back then. Before the occurrence of documented, widespread and severe riverbed alterations, rivers were able to shape their channel and migrate in floodplains, thus creating new surfaces and modelling fluvial forms through sediment erosion and deposition processes. In this dynamic contest, properties changed depending on riverbed changes, according to the aforementioned regulatory provisions: loss and increase of private plots of land occurred in case of erosion or accretion, respectively [12]. Approximately up to the 1940s, for example, many state-owned lands existed close to the Po River; they were partly granted to private citizens for agricultural use and partly left in their natural state and used as firewood source by riverine populations [8]. Subsequently, the former progressively exceeded the latter.

In the second half of the 20th century, the widespread construction of channelization works progressively blocked the river lateral dynamic and disconnected large, floodplain areas from 
the active channel [5]. Furthermore, it resulted in a decrease of the outflow section width and in triggering erosion processes due to increased stream velocity [7]. These last, in turn, made necessary further bank protections and promoted the active-channel incision, mainly boosted by severe in-channel sediment mining [5], [7]. Thus, channelization prevented new stateowned land creation, whereas riverine lands that were progressively above the ordinary-flood level became private property for free. Despite this acquisition could have occurred in case of land emergence due to natural causes only, both the outdated and unsuitable criterion for the definition of state-owned lands, and the hydraulic and agricultural interventions diffusely realized along riverbeds, substantially adapted dynamic channels to administrative requisite for privatization [8]. Moreover, the causal relationship among in-channel human alterations, channel incision, and land emersion has not long been considered. Finally, a number of stateowned plots of land are documented to have been illegally used [6], [8], [17]-[19]. This dramatic association of factors led to a progressive loss of natural lands close to riverbeds and was at the origin of the occupation of large areas of fluvial pertinence [8], [11].

To stop this tendency, the so-called 'Cutrera Law' passed in 1994 and revolutionized the legal framework by modifying the national Civil Code. Its regulations are currently in force and provide for the state ownership of land abandoned by rivers. Furthermore, they establish that in case of requests for granting this land, it has to be primarily granted to local authorities for environmental protection purposes. However, this measure does not have retroactive effect, and numerous legal disputes between the State and private landowners concerning fluvial-related land property, have long lasted after 1994. In general, they maintained the anthropic and natural origin of land emersion above the ordinary-flood level, respectively, and verdicts often resulted in land privatization, despite everything.

\section{STUDY AREA}

The Scrivia River is located in the northwestern part of Italy (Fig. 1a). It origins in the Ligurian-Piedmontese Appennines, very close to Genova, and flows approximately northward up to join the Po River, of which is one of the main right-bank tributaries. The Scrivia River is about $90 \mathrm{~km}$ long and its catchment spreads over some $1000 \mathrm{~km}^{2}$. The upper part of the valley is characterized by a mountainous landscape alternately showing a wide and narrow valley bottom associated with gentle and steep slopes, respectively. At the end of the V-shaped valley, a wide series of fluvial terraces joins up reliefs and the floodplain sector of the basin. The catchment elevation ranges between $1700 \mathrm{~m}$ a.s.l. and $67 \mathrm{~m}$ a.s.l., and the mean annual rainfall is $900 \mathrm{~mm}$ [6 and references therein]. Due to its geographical and geomorphological settings, the Scrivia River basin is prone to floods [20]. Regarding the flow rates, the mean daily discharge and the mean annual maximum discharge, measured from 2001 to 2016 at the gauging station located $5.14 \mathrm{~km}$ upstream from the Po confluence, are $14.2 \mathrm{~m}^{3} / \mathrm{s}$ and $304 \mathrm{~m}^{3} / \mathrm{s}$, respectively. From a geological point of view, sedimentary rocks belonging to the Tertiary Piedmont Basin (TPB) succession and to the Ligurian and Epiligurian Units, mostly outcrop in the hilly and mountainous part of the catchment [6].

The Scrivia River floodplain reach is about $40 \mathrm{~km}$ long and in the second half of the 20th century experienced intense active-channel narrowing and deepening processes. In that period, and particularly between the 1960s and the 1980s, it has been affected by severe human alteration, mostly consisting of in-channel sediment quarrying, channelization works and consecutive occupation of areas of fluvial pertinence [ 6 and references therein].

The study reach is the downstream part of the Scrivia River floodplain reach (Fig. 1b). It extends from the downstream consolidation check-dam to the Po River. It is $16.2 \mathrm{~km}$ long and the riverbed is narrow, sinuous, deeply incised and single-thread channel. This reach is rather 

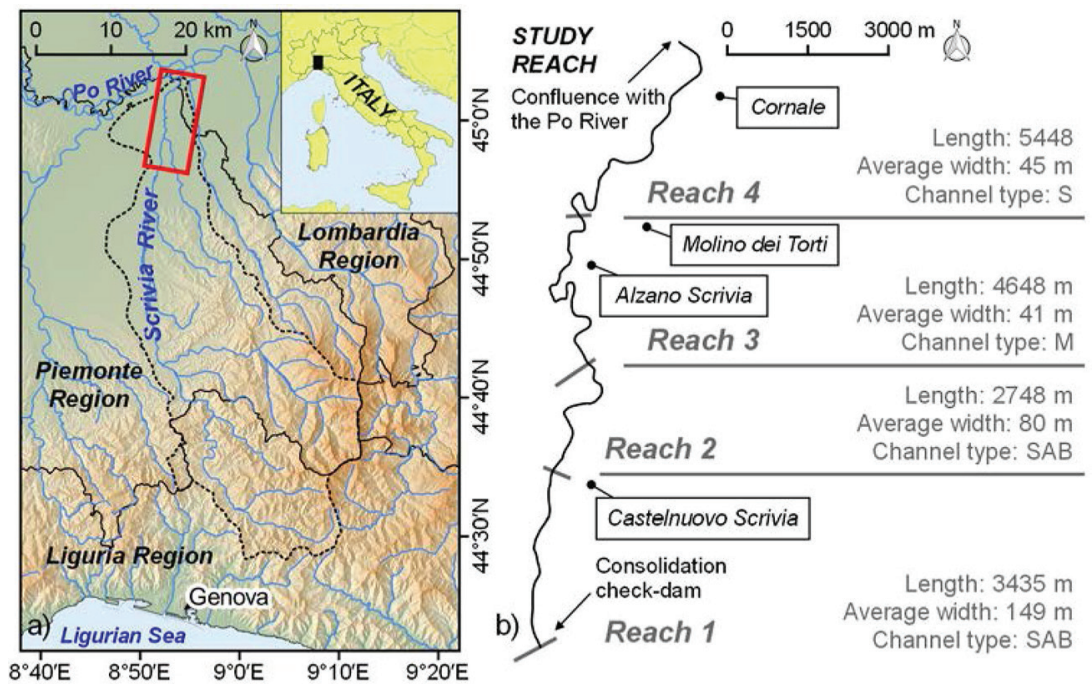

Figure 1: (a) Study reach location map. The dotted line delimits the Scrivia River catchment and the red rectangle highlights the study reach. (b) The lower Scrivia River and the main morphological features of identified reaches (related to the 2016 active channel). The rectangles indicate villages. S: sinuous; M: meandering; SAB: sinuous with alternate bars.

interesting because it represents the only portion of the Scrivia River floodplain reach where relevant active-channel location changes, mostly related to meandering process and occurring up to the 1970s, are documented in the investigated period [6]. Nowadays, a number of intense localized bank retreats and widespread bank instability processes affect the active channel.

\section{MATERIALS AND METHODS}

The active-channel planform evolution of the Scrivia River floodplain reach was outlined through a GIS-based, multi-temporal analysis widely described in a previous work [6]. Particularly, 10 different data sources covering the period from 1878 to 2016, and consisting of historical maps (dated 1878-1882 and 1922), aerial photographs (1954-1955 and 1977), orthophotos (1980, 1988, 1999, 2007 and 2012) and Google Earth satellite images (2016), were used to carry out a quantitative analysis of the active-channel planform features and adjustments. In this research, we considered also the available aerial photographs covering part of the study reach, from a 1970 flight, to more specifically describe the active-channel planform dynamics of that time, following the same methodological approach [6]. Thus, after georeferencing the 1970 aerial photographs, we digitized the active channel polygon and computed its width, area, length and sinuosity. Moreover, the percentage of non-changed active-channel area and the net channel activity were calculated to assess the riverbed lateral migration with respect to existing data [6]. The whole study reach was divided into four reaches according to homogeneous geomorphological features and the presence of in-channel works (Fig. 1). Using the same data sources, except for historical maps, we digitized the bank protection structures. Gabionades, ripraps and walls were classified as 'longitudinal defenses', whereas features like groynes as 'cross defenses'. Field survey together with archive records supported and validated remotely-sensed data. 
Regarding land use in riverine areas, we classified the historical migration zone [21], hereafter called HMZ, into four major land use classes suitable for our purposes, considering the aerial photographs of 1954, the orthophotos of 1980 and 1999, and the Google Earth satellite images of 2017. Thus, active channels, semi-natural, agricultural and artificial areas were mapped over time in order to quantify and pinpoint land-use changes. The semi-natural areas consist of woodlands, shrubs, herbaceous-vegetation areas and natural wetlands external to the active channel; the artificial areas include discontinuous and continuous urban fabric, road network, industrial areas, quarry lakes, sediment quarrying sites, embankments and spillways. Furthermore, land use was mapped in a $250 \mathrm{~m}$ buffer created around the 1954 and the 2017 active channel, following the aforementioned approach.

Finally, the active-channel polygon dated 1954 was superimposed to the 2017 land-use map in order to investigate the land-use change of the areas previously belonging to the active channel. This procedure allowed us to identify representative areas that were thus investigated in terms of land property variation, by using cadastral registers.

\section{RESULTS}

The main morphological features of the identified reaches are listed in Fig. 1b. The lower Scrivia River, and particularly the 1 st and 2 nd reaches, experienced noticeable active-channel width variations over time, as illustrated in Fig. 2a. In general, all reaches register a narrowing trend between 1922 and 1954, and an increase of width value in 1977 and 1980. Moreover, a generalized active-channel narrowing is evident from 1980 to 1999, when every reach registered its minimum width. After 1999, particularly in reaches 1 and 2, a slight reversal trend consisting of active-channel widening, is documented. The most intense narrowing is recorded from 1954 to 1970 in the 1st reach, where the active-channel width changed from $285 \mathrm{~m}$ to $137 \mathrm{~m}$, falling by $51.9 \%$. Downstream of Castelnuovo Scrivia, the active-channel width remained rather constant over time, showing a mean value of $46.1 \mathrm{~m}$ and $56.1 \mathrm{~m}$, and a range of $31 \mathrm{~m}$ and $96 \mathrm{~m}$, for the $3 \mathrm{rd}$ and 4th reaches, respectively.

Regarding sinuosity, two general tendencies are noticeable: on the one hand, reaches 1 and 4 experienced very slight variations over time, whereas, on the other hand, reaches 2 and 3 show an increase up to 1970 and 1954, respectively, followed by a decrease up to the 1980 , and later by smaller similar fluctuations (Fig. 2b).

The active-channel area trend analysis reveals an overall loss in surface of 57.4 ha $(-32.8 \%)$ and 40.1 ha (-25.9\%), from 174.8 ha in 1878 and 158.3 ha in 1954 to 117.4 ha in 2016, respectively. The lowest active-channel area (95 ha) is documented in 1999.

The net channel activity substantially follows the temporal trend documented for the active-channel width (Fig. 3). Very close-to-zero values are registered up to 1954 in reaches
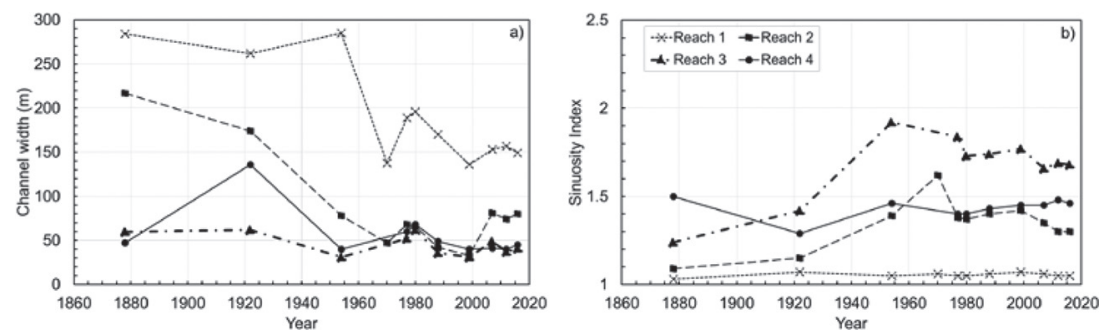

Figure 2: Active-channel average width (a) and sinuosity (b) variation over time at reach scale. 

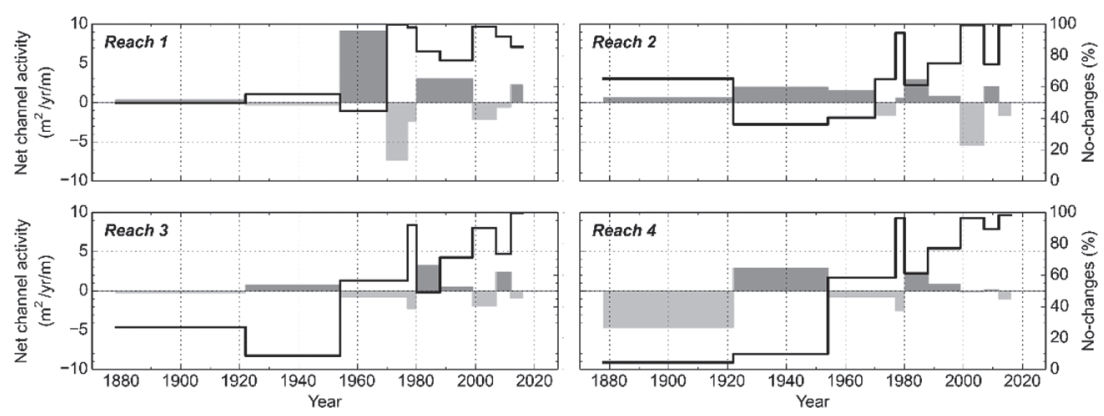

Figure 3: Net channel activity and percentage of active-channel unchanged area for each consecutive time step. The grey highlights are keyed to the left y-axis. Values higher (lower) than zero - dark (light) grey highlight - represent prevailing changes from active channel (floodplain) to floodplain (active channel). The black line is keyed to the right y-axis and represents the percentage of unchanged active-channel surface referring to the oldest riverbed of each time step.

1 and 3, and up to 1922 in the 2 nd reach. The conversion from active channel to floodplain clearly dominates in the 1st reach in the period 1954-1970, and in all reaches from 1980 to 1999 , with lower net-channel-activity values. Negative peaks show that the conversion from floodplain to active channel prevailed before 1980, particularly from 1970, for reaches 1 and 2, and 1954 for reaches 3 and 4. Furthermore, this process generally characterizes the periods 1999-2007 and 2012-2016. The net channel activity and the percentage of unchanged active-channel areas highlight the greatest planform stability in the most recent periods.

Generally, most of longitudinal bank protections were built between the second half of the 1970s and the end of the 1980s (Fig. 4). All reaches show a common temporal trend, and the whole study reach presents the $2.4 \%$ of protected banks (referred to the sum of left- and right-bank length) in 1954, $16.8 \%$ in $1977,57.8 \%$ in 1988 and $64.9 \%$ in 2016 . On the contrary, in the considered years a number of groynes were mapped only in the 1st reach, with the highest values recorded in the 1970s. The downstream three reaches have been
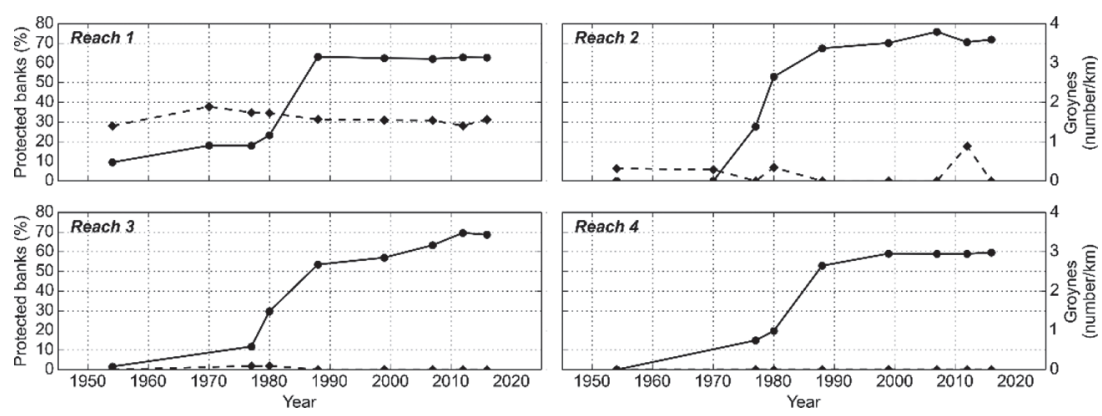

Figure 4: Presence of bank protections over time. The dashed line refers to the right $y$-axis. 
substantially without cross defenses. At the present day, the reach-scale longitudinal bank protections presence ranges between $71.9 \%$ and $59.6 \%$, measured for the 2 nd and the 4 th reach, respectively.

Figure 5a illustrates land use changes occurred in the historical migration zone over the considered period. The active-channel area slightly decreased, particularly for the Po River. The semi-natural surface, in general, does not show relevant changes, and have always been approximately $24 \%$ of the HMZ, except for a decrease recorded in 1980. At reach scale, we registered the highest semi-natural-area reduction in the 2 nd and 3rd reaches. An increase of $13.4 \%$, from $42.9 \%$ to $56.3 \%$, is documented for cultivated lands between 1954 and 1980 , whereas from 1980 onwards they have ranged between $57.2 \%$ and $53.4 \%$.

The highest artificial-area extent is noticed in 1980 (4.6\%), and then its value has remained about $1.7 \%$. At reach scale, it has always been lower than $5.1 \%$, except for the maximum value of $10.4 \%$ registered in 1980 , in the 1 st reach.

Focusing on the 250-m buffer mapped around the 1954 and 2017 active channel, an opposite temporal trend is documented for the extent of semi-natural and agricultural areas, in reaches 1, 4 and 2, 3, respectively (Table 1). Furthermore, a generalized increase of artificial areas is noticed, with the maximum value recorded in the 2 nd reach.

The comparison of land use in 1954 and 2017, at a distance of $50 \mathrm{~m}$ from the activechannel banks, reveals that cultivated land increased of $6.2 \%$, from $55.5 \%$ to $61.7 \%$, and artificial area of $2.2 \%$, from 1.2 to $3.4 \%$. On the contrary, semi-natural area decreased of $8.4 \%$, from $43.3 \%$ to $34.9 \%$. In particular, agriculture close to the riverbed augmented of $25.5 \%$ and $22.5 \%$ in the 2 nd and the 3 rd reaches, respectively, and semi-natural area decreased of $30.8 \%$ and $25.2 \%$. The 1 st reach shows an opposite trend characterized by an increase of semi-natural $(+15.9 \%)$ and a decrease of agricultural area $(-17.1 \%)$. Overall variations lower than $5 \%$ are documented in the downstream reach. Artificial area changes were substantially very low, except for the 2nd reach where an increase of $5.3 \%$ is registered.

Finally, the overlapping of the lower Scrivia River active channel dated 1954 with the landuse map dated 2017 , reveals that nowadays $9.4 \%$ of the previous active channel is agricultural surface, $48.3 \%$ is semi-natural, and the $0.7 \%$ is artificial (Fig. 5b). Considering the Scrivia River downstream of Castelnuovo Scrivia, the 1954 active-channel location is currently $38.6 \%$ and $19.4 \%$ of semi-natural and agricultural areas, respectively, whereas $41.9 \%$ has not

Table 1: Percentage values (\%) of land-use types in a $250 \mathrm{~m}$ buffer around the active channel. The symbols represent stable $(=)$, increasing $(\uparrow)$ or decreasing $(\downarrow)$ trend.

\begin{tabular}{llllllllllll}
\hline & \multicolumn{9}{c}{ Sand use type } \\
& \multicolumn{1}{c}{ Semi-natural areas } & \multicolumn{3}{c}{ Agricultural areas } & \multicolumn{3}{c}{ Artificial areas } \\
\hline Year & 1954 & 2017 & & 1954 & 2017 & & 1954 & 2017 & \\
Reach 1 & 33.5 & 50.7 & $\uparrow$ & 64.8 & 45.8 & $\downarrow$ & 1.7 & 3.6 & $\uparrow$ \\
Reach 2 & 32.7 & 18.1 & $\downarrow$ & 64.4 & 72.0 & $\uparrow$ & 2.9 & 9.9 & $\uparrow$ \\
Reach 3 & 28.3 & 13.4 & $\downarrow$ & 70.5 & 84.1 & $\uparrow$ & 1.2 & 2.5 & $\uparrow$ \\
Reach 4 & 12.7 & 20.0 & $\uparrow$ & 85.1 & 74.3 & $\downarrow$ & 2.2 & 5.6 & $\uparrow$ \\
Total & 25.4 & 25.0 & $=$ & 72.7 & 69.9 & $\downarrow$ & 1.9 & 5.1 & $\uparrow$ \\
\hline
\end{tabular}



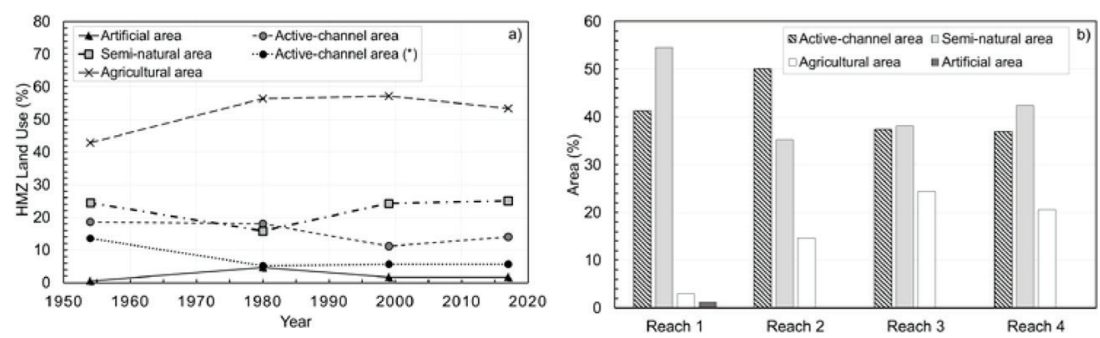

Figure 5: (a) HMZ land-use changes over time. (b) Current land use of areas belonged to the 1954 active channel.

changed. This analysis, together with the consultation of cadastral data, allowed us to identify a number of representative sites where land-use variation, particularly from active-channel to cultivated land, is strictly associated with the State-to-private land-property passage.

\section{DISCUSSION}

The study reach experienced large active-channel planform changes from 1878 to 2016. In general, two main evolutionary phases were defined according to the reach-scale, morphological-processes homogeneity: the former is characterized by different morphological tendencies, and lasted up to the 1970s; the latter presents similar morphological tendencies, and lasted from the 1970s onwards. Furthermore, a significant difference is documented overall in the first phase, between the 1 st reach and the others, in terms of morphological features and evolution. The 1st reach, in fact, experienced a braiding-channel lateral migration, maintaining the overall channel direction, and without a prevalent widening or narrowing process up to the 1950s. Subsequently, from 1954 to 1970 an intense active-channel width decrease, together with a braiding degree reduction, is documented. Differently, in sinuous and single-thread channel reaches, that is reaches located downstream of Castelnuovo Scrivia, the active-channel migration is associated with meandering and avulsion processes. The largest shifts occurred overall up to the 1950s, and continuous meandering processes are registered up to the 1970s, as highlighted by the sinuosity index.

The downstream reach experienced the widest active-channel-location change that we documented. In particular, between Molino dei Torti and the Po river, the Scrivia river was straight and flowing northwestward in 1878, whereas it was sinuous, about $2.2 \mathrm{~km}$ longer and flowing northeastward in 1922. According to historical sources, in 1887 an avulsion of the Po riverbed occurred due to an intense flood; a new channel was created and after its abandonment in the early 20th century, it became the current Scrivia active-channel [ 6 and references therein]. The increase of sinuosity and active-channel width registered between 1880s and 1920 s is related to these dynamics. Concerning land use, generally, a high percentage (about $43 \%$ ) of the HMZ was already used for agricultural purposes in the 1950s, and cultivated fields often spread up to the bank edge especially in the 1st and 4th reaches.

In the 1950s, bank protections were already conditioning the active-channel lateral migration particularly in the 1st reach. Later, in the 1970s and 1980s, widespread channelization works consisting of bank stabilization through prisms of concrete used as ripraps and artificial cut-off, were carried out along the whole study reach (Fig. 6). Channelization resulted in interrupting lateral dynamics and, thus, excluding large floodplain areas from active-channel processes. From 1954 to 1980, the HMZ registered an increase of agricultural areas and a decrease of semi-natural areas, particularly in the 2 nd and 3 rd reaches. 


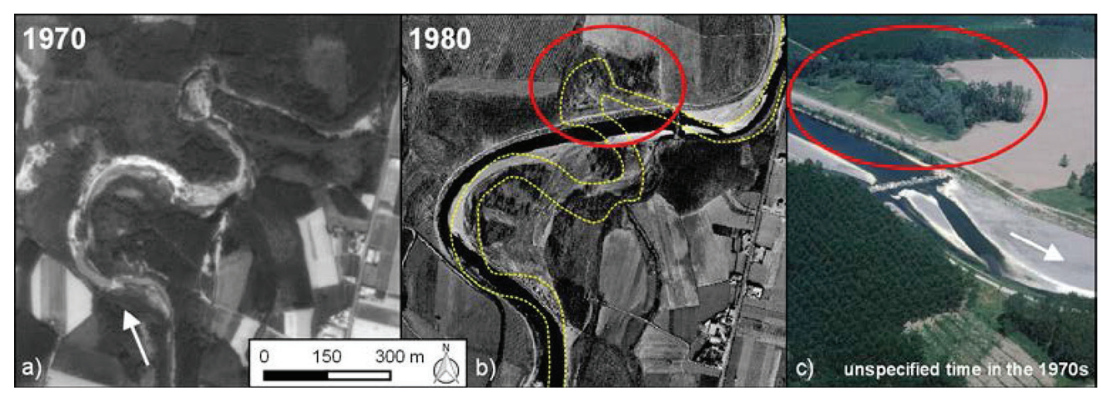

Figure 6: The Scrivia River downstream of Castelnuovo Scrivia before (a) and after (b) channelization. The dotted yellow line (b) represents the 1970 active channel (a). The red circles highlight the same area in (b) and (c). (c) Photo courtesy of Antonello Brunetti.

In the second half of the 20th century, the Scrivia River floodplain reach experienced a notable riverbed incision, most probably due to in-channel sediment quarrying. This activity caused the active-channel morphology alteration noticeable in aerial photos dated 1970 and 1980, and the highest percentage of artificial areas, registered in 1980, especially in the 1st reach. On this basis, the severe active-channel narrowing that affected the 1st reach between 1954 and 1970 can be related to the active-channel deepening, and not to bank protections, widely built after narrowing. The riverbed degradation left sedimentary bodies suspended that were progressively fixed by vegetation, and no longer involved in the active-channel dynamics. This process resulted in the active-channel, progressive and generalized narrowing documented in the 1980s and 1990s. Furthermore, it substantially caused the semi-natural and active-channel areas increase and decrease, respectively, registered in the same years.

Therefore, both the lateral-dynamics interruption and the active-channel incision are identified as the causes of the gradual disconnection between the riverbed and adjacent areas.

The well-defined, concordant variations of parameters computed in 1977 and between 1977 and 1980, are mainly due to the active-channel changes triggered by the extreme flood of the October 7-8, 1977. However, the decrease of sinuosity in the 2 nd and 3rd reaches, recorded at the end of the 1970s, is also due to channelization.

Since the early 2000s a generalized reversal trend mainly consisting of morphologicalprocesses reactivation and active-channel widening involving both the active floodplain and the recent terrace, has been documented. Its triggering factor has been substantially identified in the sequence of extreme floods occurred over the last years (in 2002, 2010, 2011, 2013, 2014) that promoted lateral-erosion and incision processes, thus causing bank-protections collapse and resulting reactivation of lateral dynamics. For this reason, further bank protections were built to stabilize some natural banks or restore ancient defenses. This accounts for the active-channel widening registered in the 2nd and 3rd reaches, in the period 1999-2007. At the present day, those works are partly undermined or already collapsed.

The comparison between 1954 and 2017 land-use map highlights on the one hand a notable increase of agricultural lands close to the riverbed in the 2 nd and $3 \mathrm{rd}$ reaches, and on the other hand an increase of semi-natural areas in the 1 st and 4 th reaches. These trends are strictly associated with the aforementioned evolutionary trends of both morphological and channelization processes.

Today, most of surfaces belonging to the active channel in 1878 and 1922 are cultivated fields, thus, generally, private plots of land. In this respect, investigated aerial photos show 


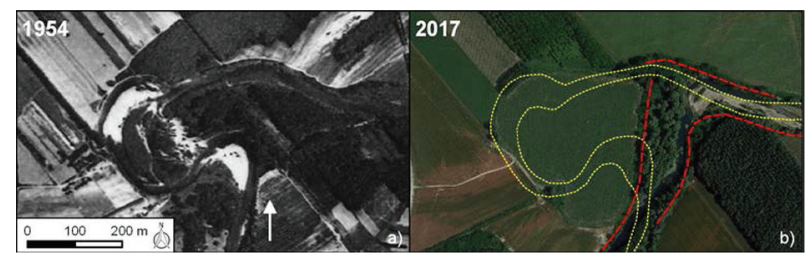

Figure 7: Example of land-use and property variation. The dotted yellow line and the dashed red line represent the 1954 active channel and the bank protections, respectively. See the text for explanation.

many curved fields, representing ancient fluvial tracks. The reduction of the Po river activechannel area included in the lower Scrivia River HMZ, is due to the northward migration of its right bank; the abandoned lands were progressively, almost completely cultivated.

At the present day, the surface occupied by the active channel in 1954, excluding what has remained active channel, is almost completely semi-natural in the 1st reach, whereas it is for one-third cultivated downstream of Castelnuovo Scrivia. Among cultivated lands belonging to the active-channel in 1954, the representative plots of lands downstream of Castelnuovo Scrivia, whose property was investigated through historical cadastral data, revealed that from state-owned land they became private property (Fig. 7). This was permitted by the regulations in force up to 1994, even if the lower Scrivia River experienced morphological changes certainly resulting from anthropic influence. Finally, the illegal practice consisting of occupying the riverine, state-owned plots of land without concession, especially by farmers, is widely documented along the study reach [18], [19]. This practice originated a citizen protest led from the 1970s to the end of the 1980s [17], [19], which, supported by the Castelnuovo Scrivia municipality, succeeded in the institution of restricted areas to preserve fluvial, that is stateowned, plots of land.

\section{CONCLUSIONS}

This study illustrates the lower Scrivia River planform changes occurred between 1878 and 2016, and outlines the channelization-works history and land-use changes close to the riverbed from the 1950s onwards. The active channel experienced a well-defined sequence of morphological evolutionary phases. In particular, we identified two periods of severe narrowing in the 20th century, separated by the extreme flood occurred in 1977. The former intensely involved only the 1st reach, and is characterized by the abandonment of large active-channel areas. The latter is registered in all reaches, and is characterized by an increase of riverbed stability, and a gradual stabilization of surfaces located between banks that were progressively fixed through bank protections. Simultaneously, the active channel and floodplain surfaces excluded from fluvial dynamics through channelization were partly farmed or occupied by quarries, facilities and infrastructure. From 1999 onwards, an inversion of morphological trends consisting of diffuse bank instability, local intense bank retreats and reactivation of stabilized surfaces is noticed. These dynamics most probably represent the morphological response to the documented, severe anthropic alterations.

In this respect, anthropic pressures on the river system, and in particular bank protections, are documented to have played a key role in driving the active-channel changes, and consequently, the land-property and the near-riverbed land-use changes. In this respect, it is evident 
that the past legal framework is also identified as a relevant conditioning factor of the rivercorridor morphological evolution. It allowed for the gradual occupation of land abandoned by the river, thus promoting the loss of riverine areas and legitimizing the resulting increase of river-related risks. Therefore, 'the stolen space' was not actually stolen, at least not in all cases. It represents the surface legally subtracted from the river, under the regulation in force.

The lower Scrivia River case study is a representative example of the influence of landproperty regulation on Italian rivers. Moreover, this research highlights the great importance of cadastral data for the analysis of landscape dynamics under the perspective of river management and risks mitigation.

Today, in a densely cultivated and urbanized landscape, as the lower Scrivia River floodplain is, the current morphological processes are raising serious management issues, as there are no rooms left for river dynamics. Generally, people and local authorities ask for new but old-school works to defend private property, but a change of perspective is needed to restore the fluvial environment and carry out sustainable and effective measures for river-related risks reduction.

\section{ACKNOWLEDGEMENTS}

We are pleased to acknowledge all people who somehow contributed to this research providing historical and legal information and data, in particular Antonello Brunetti. Furthermore, we sincerely thank Piero Mandarino, active witness of the evolution of the Italian, legal and management framework concerning rivers.

\section{REFERENCES}

[1] Scorpio, V., Aucelli, P.P.C., Giano, S.I., Pisano, L., Robustelli, G., Rosskopf, C.M. \& Schiattarella M., River channel adjustments in Southern Italy over the past 150 years and implications for channel recovery. Geomorphology, 251, pp. 77-90, 2015.

[2] Pellegrini, L., Maraga, F., Turitto, O., Audisio, C. \& Duci, G., Evoluzione morfologica di alvei fluviali mobili nel settore occidentale del bacino padano. Italian Journal of Quaternary Sciences, 21, pp. 251-266, 2008.

[3] Surian, N., Rinaldi, M., Pellegrini, L., Audisio, C., Maraga, F., Teruggi, L., Turitto, O. \& Ziliani, L., Channel adjustments in northern and central Italy over the last 200 years. In Management and Restoration of Fluvial Systems with Broad Historical Changes and Human Impacts, eds. James, L.A., Rathburn, S.L. \& Whittecar, G.R., Geological Society of America Special Paper, 451, Geological Society of America: Boulder, CO, pp. 83-95, 2009.

[4] Surian, N. \& Rinaldi, M., Morphological response to river engineering and management in alluvial channels in Italy. Geomorphology, 50, pp. 307-326, 2003.

[5] Gurnell, A., Surian, N. \& Zanoni, L., Multi-thread river channels: A perspective on changing European alpine river systems. Aquatic Sciences, 71, pp. 253-265, 2009.

[6] Mandarino, A., Maerker, M. \& Firpo M., Channel planform changes along the Scrivia River floodplain reach in northwest Italy from 1878 to 2016. Quaternary Research, 91(2), pp. 620-637, 2019.

[7] Cencetti, C., De Rosa, P. \& Fredduzzi, A., Geoinformatics in morphological study of River Paglia, Tiber River basin, Central Italy. Environmental Earth Sciences, 76, p. 128, 2017.

[8] Comitato per la difesa e la rivalutazione del Po, Italia Nostra Piemonte, Lega per l'Ambiente Piemonte, Pro Natura Piemonte \& WWF Piemonte, I Fiumi Italiani e le Calamità Artificiali, eds. Ente Riserve Naturali Garzaia di Valenza e Garzaia di Bosco Marengo: Valenza Po, 1988. (in Italian). 
[9] Cannata, P.G., La scienza dell'acqua. La Città, 9(2), 1995. (in Italian).

[10] Ercolini, M., Dalle esigenze alle opportunità: la difesa idraulica fluviale occasione per un progetto di "paesaggio terzo", PhD Thesis, Firenze, 2006. (in Italian).

[11] Ludovici, A.A. (eds), Salviamo i fiumi. Guida pratica per le amministrazioni comunali lombarde, WWF Lombardia: Milano, 1997. (in Italian).

[12] Mandarino, P., Una speranza per i fiumi: la legge Cutrera, L'InformaFiume-Notiziario del Parco Fluviale del Po e dell'Orba, 1, p. 11, 1995. (in Italian).

[13] Mandarino, P., Appartengono al demanio pubblico i terreni abbandonati dai fiumi. Territorio e Provincia, 1994. (in Italian).

[14] Mandarino, P., Norme per la tutela ambientale dei fiumi, torrenti, acque pubbliche. Territorio e Provincia, 1994. (in Italian).

[15] Clerici, A., Perego, S., Chelli, A. \& Tellini, C., Morphological changes of the floodplain reach of the Taro River (Northern Italy) in the last two centuries. Journal of Hydrology, 527, pp. 1106-1122, 2015.

[16] Bollati, I.M., Pellegrini, L., Rinaldi, M., Duci, G. \& Pelfini, M., Reach-scale morphological adjustments and stages of channel evolution: The case of the Trebbia River (northern Italy). Geomorphology, 221, pp. 176-186, 2014.

[17] Regalzi, E., Scrivia, il primo parco. La Stampa - Alessandria. July 14, 1989. (in Italian).

[18] Brunetti, A., Ormai imminente il 'Parco dello Scrivia'. Il Gazzettino, 5, 1987. (in Italian).

[19] Brunetti, A., Speciale Parco dello Scrivia. Il Gazzettino, 6, 1987. (in Italian).

[20] Pepe, G., Mandarino, A., Raso, E., Cevasco, A., Firpo, M. \& Casagli, N., Extreme flood and landslides triggered in the Arroscia Valley (Liguria Region, Northwestern Italy) during the November 2016 rainfall event. In Engineering Geology for a Sustainable World, eds. Shakoor, A. \& Cato, K., IAEG/AEG Annual Meeting Proceedings, San Francisco, California, 2018, Volume 1, Springer, Cham, pp. 171-175, 2019.

[21] Rapp, C.F. \& Abbe, T.B., A Framework for Delineating Channel Migration Zones. Ecology Publication No. 03-06-027, Washington State Department of Ecology and Department of Transportation, Lacey, WA, 2003. 